\title{
ACESSIBILIDADE COMO UM DIREITO FUNDAMENTAL: UMA ANÁLISE À LUZ DAS LEIS FEDERAIS BRASILEIRAS
}

\author{
ACCESSIBILITY AS A FUNDAMENTAL RIGHT: AN ANALYSIS IN THE LIGHT OF \\ BRAZILIAN FEDERAL LAWS
}

\section{ACCESIBILIDAD COMO UN DERECHO FUNDAMENTAL: UN ANÁLISIS A LA LUZ DE LAS LEYES FEDERALES BRASILEÑAS}

\author{
Susana Couto Pimentel \\ http://orcid.org/0000-0002-6047-3198 / http://lattes.cnpq.br/6636602535604435 / scpimentel@ufrb.edu.br \\ Doutora em Educação. Professora Associada da Universidade Federal do Recôncavo da Bahia (UFRB). Docente do \\ Mestrado Profissional em Gestão de Políticas Públicas e Segurança Social. \\ Cruz das Almas, BA, Brasil.
}

Mariana Couto Pimentel

http://orcid.org/0000-0002-8520-2140 / http://lattes.cnpq.br/5652569991583487 / dra.marianacouto@gmail.com Advogada. Especialista em Direito Tributário.

Cachoeira, BA, Brasil.

\begin{abstract}
RESUMO
Esta investigação objetiva analisar como a acessibilidade da pessoa com deficiência é assegurada no ordenamento jurídico brasileiro infraconstitucional como um direito fundamental. No Brasil, a Constituição de 1988 traz uma gama de direitos fundamentais para que os indivíduos sejam respeitados como pessoas na sociedade, limitando o poder do Estado. Entretanto, as pessoas com deficiência historicamente têm sido privadas de muitos direitos frente a uma sociedade não acessível e excludente. A metodologia deste trabalho é a pesquisa bibliográfica, de cunho exploratório, tomando as normas jurídicas brasileiras como referência de análise. Os resultados evidenciam leis infraconstitucionais que tratam da acessibilidade de modo intimamente relacionado com três dos principais direitos fundamentais: à vida, à liberdade e à igualdade. Conclui-se que, apesar de não estar explicitamente elencada na Carta Magna, a acessibilidade é um direito fundamental, pois garante a dignidade da pessoa com deficiência.
\end{abstract}

Palavras-chave: Acessibilidade; Dignidade Humana; Direitos Fundamentais; Pessoa com deficiência.

\section{ABSTRACT}

This research aims to analyze how the accessibility of disabled people is ensured in the infraconstitutional Brazilian legal system as a fundamental right. In Brazil, the Constitution of 1988 brings a range of fundamental rights for individuals to be respected as a person in society, limiting the power of the state. However, people with disabilities historically have been deprived of many rights in a not accessible and exclusionary society. The methodology of this work is the bibliographical research, of exploratory nature, taking Brazilian legal norms as reference of analysis. The results evidence infraconstitutional laws that deal with accessibility in a way closely related to three of the main fundamental rights: life, liberty and equality. It is concluded that, although not explicitly listed in the Constitution, accessibility is a fundamental right, as it guarantees the dignity of the disabled person.

Keywords: Accessibility; Human Dignity; Fundamental Rights; People with disabilities.

\section{RESUMEN}

Esta investigación tuvo como objetivo analizar cómo se garantiza la accesibilidad de la persona con discapacidad en el sistema jurídico brasileño infraconstitucional como un derecho fundamental. En Brasil, la Constitución de 1988 trae una serie de derechos fundamentales para que los individuos sean respetados por sus singularidades, limitando el 
poder del Estado. Sin embargo, las personas con discapacidad, históricamente, se han visto privadas de muchos derechos por una sociedad no accesible y que aparta a los distintos. La metodología de este trabajo fue la investigación bibliográfica, exploratoria, tomando las normas jurídicas brasileñas como referencia de análisis. Los resultados evidencian leyes infraconstitucionales que tratan la accesibilidad de modo analogo a tres de los principales derechos fundamentales: la vida, la libertad y la igualdad. Se concluye que, aunque no sea mencionada explícitamente en la Carta Magna, la accesibilidad es un derecho fundamental, ya que garantiza la dignidad de la persona con discapacidad.

Palabras clave: Accesibilidad; Dignidad Humana; Derechos Fundamentales; Persona con discapacidad.

\section{SUMÁRIO}

INTRODUÇÃO; 1 DIREITOS FUNDAMENTAIS: NÚCLEO INVIOLÁVEL DE UMA SOCIEDADE PARA A GARANTIA DA DIGNIDADE DA PESSOA HUMANA; 1.1 Dimensões dos Direitos Fundamentais; 1.2 Características dos Direitos Fundamentais; 2 DIRECIONAMENTOS DO ORDENAMENTO JURÍDICO BRASILEIRO SOBRE A ACESSIBILIDADE COMO UM DIREITO FUNDAMENTAL DA PESSOA COM DEFICIÊNCIA; 2.1 A Constituição Federal $e$ as legislações infraconstitucionais federais que tutelam a acessibilidade da pessoa com deficiência; 2.2 A acessibilidade como um direito fundamental da pessoa com deficiência; CONCLUSÃO; REFERÊNCIAS.

\section{INTRODUÇÃO}

$\mathrm{Na}$ sociedade contemporânea, o conceito de acessibilidade é compreendido como mais abrangente do que envolvendo meramente questões relativas a edificações, sendo estas apenas um aspecto que o envolve. Entende-se, assim, que as condições de acessibilidade abarcam, dentre outras questões, o acesso à informação e à comunicação, ao transporte, bem como a equipamentos e mobiliários que permitam o uso de todos os cidadãos. ${ }^{1}$

Essa concepção mais abrangente da acessibilidade está inserida no paradigma da inclusão social das pessoas com deficiência e parte do princípio da garantia dos seus direitos, estabelecidos desde a aprovação da Declaração dos Direitos Humanos pela Organização das Nações Unidas (ONU) em 1948.

Destaca-se que essa perspectiva mais ampliada do conceito de acessibilidade está relacionada à modificação do conceito de deficiência ao longo do tempo. Hoje se entende que a adequação do entorno, no qual estão inseridas tais pessoas, pode potencializar ou não a condição da deficiência. Esse conceito, ratificado pela Convenção sobre os Direitos das Pessoas

\footnotetext{
1 BRASIL. Lei $n^{\circ} 10.098$, de 19 de dezembro de 2000. Estabelece normas gerais e critérios básicos para a promoção da acessibilidade das pessoas portadoras de deficiência ou com mobilidade reduzida, e dá outras providências. Diário Oficial da União, Brasília, 20 dez. 2000. Disponível em: http://www.planalto.gov.br/ccivil_03/leis/L10098.htm. Acesso em: 28 jun. 2017.
} 
com Deficiência, considera que a deficiência pode ter origem de ordem física, intelectual ou sensorial, e tais limitações orgânicas podem ser potencializadas através da interação com as barreiras impostas por um entorno excludente, o que acaba por impedir ou dificultar a plena participação dessas pessoas na sociedade, com equidade de condições com as demais. ${ }^{2}$

Ante ao exposto, a presente pesquisa é norteada pela seguinte questão: como, no ordenamento jurídico brasileiro infraconstitucional, mais precisamente nas leis federais, e em consonância com a Constituição Federal, é assegurada e associada à acessibilidade da pessoa com deficiência como um Direito Fundamental?

Com base nesse problema, este trabalho tem como objetivo geral analisar as leis infraconstitucionais federais a respeito da acessibilidade das pessoas com deficiência. Para esse intento, traçaram-se os seguintes objetivos específicos: Refletir sobre a acessibilidade como um direto fundamental, partindo da identificação dos direitos elencados no art. $5^{\circ}$ da Carta Magna; e analisar as leis federais a respeito da acessibilidade da pessoa com deficiência, buscando estabelecer relações com os direitos que garantem a dignidade da pessoa humana.

A metodologia utilizada para o desenvolvimento deste trabalho pauta-se na pesquisa bibliográfica, de natureza exploratória, sendo a análise feita a partir de estudos já desenvolvidos por outros autores, bem como da legislação brasileira.

Considerando-se a abordagem do problema, a presente pesquisa é classificada como de natureza qualitativa, pois buscou compreender a problemática da acessibilidade como um direito fundamental a partir de uma leitura interpretativa das leis federais. No entanto, ressalte-se que essa compreensão foi alcançada por meio de análise, reflexão e atribuição de significado dos dados levantados nos materiais consultados.

Para discussão dessa temática, este artigo está dividido em duas seções. A primeira seção, de revisão conceitual, aborda o direito fundamental, suas dimensões e características. Já a segunda seção discute direcionamentos do ordenamento jurídico brasileiro sobre a acessibilidade da pessoa com deficiência, buscando analisá-la como um direito fundamental.

\footnotetext{
2 BRASIL. Decreto № 6.949, de 25 de agosto de 2009. Promulga a Convenção Internacional sobre os Direitos das Pessoas com Deficiência e seu Protocolo Facultativo, assinados em Nova York, em 30 de março de 2007. Diário Oficial da União, Brasília, DF, 26 ago. 2009. Disponível em: http://www.planalto.gov.br/ccivil_03/_ato2007-2010/2009/decreto/d6949.htm. Acesso em: 3 jul. 2017.
} 


\section{DIREITOS FUNDAMENTAIS: NÚCLEO INVIOLÁVEL DE UMA SOCIEDADE}

\section{PARA A GARANTIA DA DIGNIDADE DA PESSOA HUMANA}

A organização político-social do Estado impõe a existência de um poder soberano, acima da população, agindo como mandatário e decidindo os destinos de uma nação. A repartição desse poder para legislar, julgar e executar leis já existentes faz com que os indivíduos pertencentes à sociedade fiquem subjugados a determinações deste poder soberano. Assim, na busca da limitação a este poder, encontramos os Direitos Fundamentais, podendo ser entendidos como Direitos de Defesa, ou seja, aqueles que defendem e protegem a sociedade para que o Estado não viole a dignidade individual de cada cidadão ${ }^{3}$.

Em uma definição jurídica, Pinho defende os direitos fundamentais como sendo uma prestação negativa do Estado ${ }^{4}$. Comparando com o direito das obrigações, poder-se-ia dizer que seria uma obrigação de "não fazer" do Estado em prol do cidadão, ou seja, corresponderia à limitação do Estado, no que tange à intervenção na vida pessoal do indivíduo. O referido autor entende que o indivíduo deixa de ser um mero súdito do Estado, passando à condição de cidadão, que possui direitos que serão resguardados pelo próprio Estado. Desse modo, os direitos fundamentais foram criados para que o cidadão deixasse de estar à mercê da vontade do Estado, passando a ter garantias personalíssimas que teriam de ser respeitadas por ele.

Assim, é válido compreender os Direitos Fundamentais como sendo direitos objetivamente reconhecidos e positivados no ordenamento jurídico de determinado Estado. No Brasil, esses direitos estão sistematizados na Constituição da República Federativa do Brasil de 1988, na qual se estabelece um rol de garantias à sociedade, sendo elencados, principal, porém não unicamente, no artigo $5^{\circ}$. Vale salientar que esses direitos (à vida, saúde, liberdade, ao trabalho, etc.) não estão restritos apenas à Constituição da República, sua abrangência engloba muito mais do que ali disposto 5 .

Segundo Mendes e Branco, os direitos fundamentais nem sempre foram os mesmos em todas as épocas, o resultado do atual conjunto desses direitos foi fruto de uma evolução

\footnotetext{
${ }^{3}$ MORAES, Alexandre de. Direito Constitucional. São Paulo: Atlas, 2010.

4 PINHO, Rodrigo César Rebello. Teoria Geral da Constituição e Direitos Fundamentais. São Paulo: Saraiva, 2002.

5 PFAFFENSELLER, Michelli. Teoria dos direitos fundamentais. 2007. Disponível em: http://www.planalto.gov.br/ccivil_03/revista/Rev_85/artigos/MichelliPfaffenseller_rev85.htm. Acesso em: 2 abr. 2014.
} 
histórica ${ }^{6}$. Como ponto de partida, observa-se no Cristianismo o início do acolhimento da defesa da ideia de dignidade humana, a partir da visão do homem como imagem e semelhança de Deus, trazendo à natureza humana um alto valor que norteou a própria normatização do direito à época.

Com a concepção das teorias contratualistas, isto é, aquelas teorias que se preocupavam em apontar a origem do poder do Estado, nos séculos XVII e XVIII, expôs-se a defesa de que certos direitos preexistem ao próprio Estado, pelo fato de serem resultados da essência da natureza humana, aflorando a principal característica do Estado que é a de servir ao cidadão. Em outras palavras, o Estado é uma instituição preservadora e garantidora dos direitos básicos de um indivíduo. ${ }^{7}$

Tais ideias foram de influência crucial na Declaração de Direitos de Virgínia - Estados Unidos - de 1776, a qual foi elaborada para proclamar direitos naturais e positivados inerentes ao ser humano, bem como na Declaração Francesa, de 1789, que proporcionou o rompimento com a monarquia absoluta. Desta forma, entende-se a segunda metade do século XVII como época de grande relevância no desenvolvimento dos direitos fundamentais que até aquele momento eram tratados e defendidos em reivindicações políticas e filosóficas e não em normas escritas, exigíveis judicialmente ${ }^{8}$. Cabe salientar que as grandes revoluções burguesas do final do século XVIII (Revolução Americana, em 1776; Revolução Francesa, em 1789) também trouxeram grande influência na criação dos Direitos Fundamentais ${ }^{9}$, principalmente da luta empreendida contra a escravidão.

Os direitos fundamentais ganham posição relevante, segundo Mendes e Branco, no momento em que se transfere do Estado para o indivíduo à posição de destaque na relação entre ambos, ou seja, quando se reconhece o ser humano como sendo portador, primeiramente, de direitos, e, depois, de deveres diante do Estado ${ }^{10}$. Assim, os deveres que o Estado possui são todos focados na garantia da tutela das necessidades do indivíduo.

\subsection{Dimensões dos Direitos Fundamentais}

\footnotetext{
${ }^{6}$ MENDES, Gilmar Ferreira; BRANCO, Paulo Gustavo Gonet. Curso de Direito Constitucional. 7. ed. São Paulo: Saraiva, 2012.

7 Ibidem.

8 Ibidem.

9 PINHO, Rodrigo César Rebello. Teoria Geral da Constituição e Direitos Fundamentais. São Paulo: Saraiva, 2002.

${ }^{10}$ Ibidem.
} 
A doutrina jurídica, com base em alguns critérios, classifica os Direitos Fundamentais em três dimensões ${ }^{11}$. Essa classificação baseia-se na ordem cronológica em que esses direitos passaram a ser constitucionalmente reconhecidos, sendo relacionados com o lema da revolução francesa: "Liberdade, Igualdade e Fraternidade"12. Vale salientar que há doutrinadores que defendem uma quarta dimensão de direito que seria a mais atual. Segundo Bonavides ${ }^{13}$, essa quarta dimensão abrange a globalização política e nela está o direito à democracia, à informação e ao pluralismo político.

Os direitos de primeira dimensão, os quais se relacionam com a “liberdade”, são aqueles que dizem respeito à liberdade pública e aos direitos civis e políticos. Pode-se dizer, portanto, que esses direitos de primeira dimensão impõem restrições ao Estado, na garantia da liberdade do indivíduo, determinando um "não fazer" ao Estado. Estes direitos são também conhecidos como "liberdades negativas" ou direitos de defesa do indivíduo frente ao Estado". Tais direitos não analisam a sociedade como um todo, pelo contrário, esta primeira dimensão é personalíssima; tem como titular o indivíduo por si só; valoriza primeiro o homem-singular, o homem das liberdades abstratas e, segundo defende Bonavides, demonstra faculdades ou atributos da pessoa e tem a subjetividade como seu traço mais característico ${ }^{15}$.

Podem ser trazidos como exemplos de Direitos Fundamentais de primeira dimensão os direitos à vida, à liberdade, ou seja, direitos individuais do cidadão, previstos no caput do artigo $5^{\circ}$ da Constituição Federal de 1988. Derivados de tais direitos, também podem ser destacados como direitos de primeira dimensão na Constituição brasileira as liberdades de manifestação (art. $\left.5^{\circ}, I V\right)$, de associação (art. $\left.5^{\circ}, \mathrm{XVII}\right)$ e o direito de voto (art. 14, caput) ${ }^{16}$.

Por sua vez, os chamados direitos de segunda dimensão são aqueles que estão comparados à "igualdade", que privilegiam os direitos sociais, culturais e econômicos. Tais direitos têm como momento histórico e impulsionador a Revolução Industrial na Europa, século XIX. Nesse período, a sociedade era submetida a condições sub-humanas de trabalho, ademais, o

11 Expressão também utilizada como "gerações" pelo Constitucionalista Paulo Bonavides, a qual foi criticada por parte da doutrina por trazer uma ideia de sucessão, substituição, embora os direitos fundamentais não se sobreponham.

${ }^{12}$ MORAES, Alexandre de. Direito Constitucional. São Paulo: Atlas, 2010.

13 BONAVIDES, Paulo. Curso de Direito Constitucional. São Paulo: Malheiros, 2011.

14 PINTO, Alexandre Guimarães Gavião. Direitos fundamentais - legítimas prerrogativas de liberdade, igualdade $\quad$ e $\quad$ dignidade. 2010.2 Disponível em: http://www.tjrj.jus.br/c/document_library/get_file?uuid=ae67daf5-7ca9-408c-93b6-b58186a81197.

Acesso em: 31 mar. 2014.

15 Ibidem.

16 PFAFFENSELLER, Michelli. Teoria dos direitos fundamentais. 2007. Disponível em: http://www.planalto.gov.br/ccivil_03/revista/Rev_85/artigos/MichelliPfaffenseller_rev85.htm. Acesso em: 2 abr. 2014. 
início do século XX foi marcado pela Primeira Grande Guerra e pela luta pelos direitos sociais, tendo como marco a Constituição de Weimar, na Alemanha, em 1919, e o Tratado de Versalhes, 1919 (Organização Internacional do Trabalho). Vale destacar que estes direitos eram trazidos como de importância menor do que os direitos de primeira dimensão, entretanto, a partir de análise apropriada, foi considerado que os direitos sociais eram tão importantes quanto os direitos de salvaguardar os indivíduos, pois protegiam não apenas o indivíduo, como também a sociedade como um todo.

Os direitos considerados de segunda dimensão estão elencados, na Constituição brasileira de 1988, em capítulo específico, denominado "Dos Direitos Sociais", onde estão enumerados diversos Direitos Fundamentais, dentre os quais o direito a educação, saúde, trabalho, moradia, lazer, segurança e previdência social (art. $6^{\circ}$, caput).

Por fim, estão os direitos de terceira dimensão correlacionados com a "fraternidade". Esses são direitos difusos, que englobam o direito a um meio ambiente equilibrado, qualidade de vida, progresso, paz, dentre outros, que tutelam quantidade indeterminada de pessoas. São considerados como direitos de terceira dimensão os direitos metaindividuais, direitos difusos, coletivos e individuais homogêneos, ligados ao princípio da solidariedade, nos quais os titulares são grupos ou categorias de pessoas.

No fim do século XX, cristalizaram-se dentre esses direitos os que não estavam ligados nem ao indivíduo, nem a um grupo social, mas sim a todo gênero humano - eram discutidos temas como paz, meio ambiente, comunicação e patrimônio comum da humanidade, por isso eram relacionados com a "fraternidade", por abrangerem a proteção a seres humanos indeterminados.

É importante salientar que alguns doutrinadores, a exemplo de Bonavides ${ }^{17}$, entendem que há uma quarta dimensão de direitos, os quais surgem junto à globalização política na esfera da normatividade jurídica. São eles os direitos à informação, à democracia e ao pluralismo. Esses direitos formam o ápice da pirâmide dos Direitos Fundamentais. Para Bonavides, "os direitos de quarta dimensão compendiam o futuro da cidadania e o porvir da liberdade de todos os povos. Tão somente com eles será legítima e possível a globalização política"18.

Vale ressaltar que há uma linha minoritária que defende dentre os direitos da quarta dimensão aqueles relacionados à engenharia genética, os quais tutelam as manipulações do patrimônio genético se ocupando do redimensionamento de conceitos e limites biotecnológicos,

\footnotetext{
17 BONAVIDES, Paulo. Curso de direito constitucional positivo. São Paulo: Malheiros, 2002.

18 Ibidem. p. 526.
} 
tratando-se, assim, de direitos fundamentais relativos à humanidade. Entretanto, a maioria dos doutrinadores segue o defendido por Bonavides ${ }^{19}$, que entende a quarta dimensão como sendo, em suma, os direitos políticos.

\subsection{Características dos Direitos Fundamentais}

Assim como conceituar os direitos fundamentais é uma árdua tarefa, fixar características para estes também o é, entretanto, segundo Mendes e Branco, apesar de não uniformes, são seis as primordiais características que se pode dar aos direitos fundamentais, a saber: direitos universais e absolutos; historicidade; inalienabilidade/indisponibilidade; constitucionalização; vinculação dos Poderes Públicos e aplicabilidade imediata ${ }^{20}$.

Ao se tratar de direitos universais e absolutos, a priori extrai-se a universalidade, posto que toda a sociedade é considerada titular desses direitos. A condição de ser humano é, portanto, a única necessária para que se possuam todos esses direitos. Por outro lado, em se tratando do garantidor desses direitos fundamentais, em sua maioria o Estado, há situações em que tal garantia é exigida não apenas do Poder Público, mas também de particulares. Nesse sentido, é possível reconhecer, também, os direitos fundamentais como absolutos, tendo em vista que estão no mais alto patamar da hierarquia jurídica e por não admitirem restrições ${ }^{21}$.

Apesar de entender os direitos fundamentais como absolutos por essência, posto que foram criados para a limitação do poder do Estado sobre os cidadãos, Mendes e Branco concluem que tal característica se tornou questionável e discutível, tendo em vista que, ao serem confrontados com valores de ordem constitucional e até mesmo com outros direitos fundamentais, estes podem ser relativizados ${ }^{22}$.

O caráter de historicidade possuído pelos direitos fundamentais decorre de que tais direitos podem ser promulgados em determinadas épocas da história, mas também podem desaparecer ou sofrer mudanças dependendo do período histórico vivido, revelando-se a índole evolutiva desses direitos. Tal evolução se dá na luta social por novas liberdades em face dos poderes antigos, como também expõem Mendes e Branco ${ }^{23}$.

Mendes, Coelho e Branco, ao tratarem da historicidade, afirmam que:

\footnotetext{
${ }^{19}$ BONAVIDES, Paulo. Curso de direito constitucional positivo. São Paulo: Malheiros, 2002.

${ }^{20}$ MENDES, Gilmar Ferreira; BRANCO, Paulo Gustavo Gonet. Curso de Direito Constitucional. 7 ed. São Paulo: Saraiva, 2012.

${ }^{21}$ Ibidem.

22 Ibidem.

23 Ibidem.
} 
a ilustração de interesse prático acerca do aspecto da historicidade dos direitos fundamentais é dada pela evolução que se observa no direito a não receber pena de caráter perpétuo. Tanto a Constituição atual quanto a anterior estabeleceu vedação à pena de caráter perpétuo. Esse direito, que antes de 1988 se circunscrevia à esfera das reprimendas penais, passou a ser também aplicável a outras espécies de sanções. Em fins de 1988, o STF, confirmando acórdão do STJ, estendeu a garantia ao âmbito das sanções administrativas. A confirmar o caráter histórico-evolutivo - e, portanto, não necessariamente uniforme - da proteção aos direitos fundamentais, nota-se, às vezes, descompasso na compreensão de um mesmo direito diante de casos concretos diversos. Assim, não obstante o entendimento do STF acima mencionado, a Corte durante bom tempo continuou a admitir a extradição para o cumprimento de penas de caráter perpétuo, jurisprudência somente revista em $2004 .^{24}$

Além dessa historicidade, uma característica marcante dos direitos fundamentais é a inalienabilidade ou indisponibilidade. Segundo Ferrajoli, a inalienabilidade baseia-se no fato de que os direitos fundamentais são normativamente direitos de toda a coletividade, por isso não são alienáveis ou negociáveis, já que correspondem a prerrogativas não contingentes e inalteráveis de seus titulares e a outros tantos limites e vínculos inarredáveis para todos os poderes, tanto públicos como privados ${ }^{25}$.

Da mesma forma que o homem não pode deixar de ser homem, não pode ser livre para ter ou não dignidade, o que acarreta que o Direito não pode permitir que o homem se prive da sua dignidade. ${ }^{26}$

Deste modo, é possível afirmar que nem todos os direitos fundamentais seriam inalienáveis, tendo em vista que possuiriam esta característica somente aqueles que objetivariam resguardar a potencialidade do homem e de sua autodeterminação. Nesses casos é inadmissível a negociação desses direitos.

A característica de constitucionalização diz respeito a esses direitos estarem consagrados em preceitos de ordem jurídica, ou seja, se estão inscritos em diplomas normativos de cada estado, bem como do Estado maior (país). São direitos concretos, positivados, vigentes em ordenamentos jurídicos fixos, assegurados na medida em que cada estado os impõe em suas legislações. No Brasil, esses direitos fundamentais se definem também como direitos

\footnotetext{
${ }^{24}$ MENDES, Gilmar Ferreira; COELHO, Inocêncio Mártires; BRANCO, Paulo Gustavo Gonet. Curso de direito constitucional. 3. ed. São Paulo: Saraiva, 2008. p. 242.

${ }^{25}$ FERRAJOLI, Luigi. Derechos y garantías. La ley del más débil. Madrid: Trotta, 1999.

${ }^{26}$ MENDES, Gilmar Ferreira; BRANCO, Paulo Gustavo Gonet. Curso de Direito Constitucional. 7. ed. São Paulo: Saraiva, 2012. p. 165.
} 
constitucionais, porque, em sua maioria, estão detalhados no Título II "Dos Direitos e Garantias Fundamentais"27.

Voltando a conceituação inicial do que seriam direitos fundamentais, é possível relacioná-los com outra característica, a vinculação aos Poderes Públicos. Como os direitos fundamentais são direitos de proteção e de limitação ao poder ilimitado do Estado, entende-se, deste modo, que nenhum dos Poderes Públicos (Legislativo, Executivo e Judiciário) é superior aos direitos fundamentais. Sendo assim, todo e qualquer ato dos poderes constituídos deve estar em conformidade com os direitos fundamentais, se expondo, conforme Mendes e Branco, à invalidade, caso os desprezarem ${ }^{28}$.

Por fim, a última característica dos direitos fundamentais é a aplicabilidade imediata, conforme reza o art. $5^{\circ}, \$ 1^{\circ}$ da Constituição Federal de 1988. Tal cláusula salienta que os direitos fundamentais são normas de caráter preceptivo e diretamente reguladoras de relações jurídicas, não dependendo de outra norma ulterior para que sua eficácia entre em vigor.

Art. $5^{\circ}$ Todos são iguais perante a lei, sem distinção de qualquer natureza, garantindo-se aos brasileiros e aos estrangeiros residentes no País a inviolabilidade do direito à vida, à liberdade, à igualdade, à segurança e à propriedade, nos termos seguintes:

[...]

$\S 1^{\circ}$ - As normas definidoras dos direitos e garantias fundamentais têm aplicação imediata. ${ }^{29}$

A ideia de que um direito é imediatamente aplicável vem da possibilidade de afirmação que o preceito inscrito é autossuficiente, que tal preceito não tem a necessidade de qualquer ato legislativo ou administrativo que anteceda a decisão na qual se consume a sua efetividade, ou seja, que este é bastante em si só.

No entanto, vale ressaltar que, apesar da característica de aplicabilidade imediata das normas constitucionais, dentre elas as normas de direito fundamental, há apenas uma exceção que a Constituição delega a uma lei posterior que a trate ou regulamente. Assim, para ter a aplicabilidade plena e imediata, essa norma dependerá de lei ulterior que a defina.

\footnotetext{
${ }^{27}$ MENDES, Gilmar Ferreira; BRANCO, Paulo Gustavo Gonet. Curso de Direito Constitucional. 7. ed. São Paulo: Saraiva, 2012.

${ }^{28}$ Ibidem.

${ }^{29}$ BRASIL. Constituição Federal. Diário Oficial da República Federativa do Brasil, Brasília, 5 out. 1988. Disponível em: http://www.planalto.gov.br/ccivil_03/constituicao/constituicao.htm. Acesso em: 28 jun. 2017.
} 


\section{DIRECIONAMENTOS DO ORDENAMENTO JURÍDICO BRASILEIRO SOBRE A ACESSIBILIDADE COMO UM DIREITO FUNDAMENTAL DA PESSOA COM DEFICIÊNCIA}

Após a exploração do conceito dos direitos fundamentais, cabe nesta seção expor as leis infraconstitucionais federais a respeito da deficiência, além de trazer o que na Constituição Federal é garantido ao indivíduo com deficiência. Busca-se correlacionar a acessibilidade com determinados direitos fundamentais que estão intimamente ligados, demonstrando, assim, como o ordenamento jurídico brasileiro assegura a acessibilidade como um direito fundamental, dando a ela grande importância, desde a preocupação em dispor sinalização em locais que são acessíveis a determinadas pessoas com deficiência, até na disposição de normas para construção de edifícios e logradouros que sejam acessíveis a todos.

\subsection{A constituição federal e as legislações infraconstitucionais federais que tutelam a acessibilidade da pessoa com deficiência}

A Constituição da República de 1988 preocupou-se, por diversas vezes, em tratar os direitos, em geral, das pessoas com deficiência, chamando para a responsabilidade do Estado o dever de proporcionar o exercício, de fato, dos direitos individuais e sociais. É importante que seja feito um apanhado geral de como a Constituição vê a pessoa com deficiência e, logo após, tratar a respeito de sua disposição acerca da acessibilidade, bem como a disposição das legislações infraconstitucionais, aquelas leis que, apesar de serem importantes para o ordenamento jurídico brasileiro, estão submetidas à Constituição da República.

$\mathrm{Na}$ Carta Magna, o primeiro artigo a tutelar a este respeito é o artigo $7^{\circ}$, inciso XXXI, o qual, ao tratar sobre direitos do trabalhador, proíbe qualquer discriminação no tocante ao salário e aos critérios de admissão da pessoa com deficiência. Tal norma vem ao encontro de alguns princípios da República, principalmente o da dignidade da pessoa humana que será tratado a posteriori. A Carta Magna entendeu que o acesso ao trabalho não é apenas uma questão de subsistência material, mas além disso um meio de interação social do ser humano, por isso a busca pela não segregação e não preconceito com relação à pessoa com deficiência ${ }^{30}$.

30 JANCZESKI, Célio Armando (Coord.). Constituição Comentada. Curitiba: Juruá, 2011. 
Art. $7^{\circ}$ - São direitos dos trabalhadores urbanos e rurais, além de outros que visem à melhoria de sua condição social:

(...)

XXXI - proibição de qualquer discriminação no tocante a salário e critérios de admissão do trabalhador portador de deficiência. ${ }^{31}$

Por conseguinte, nos artigos 23 e 24, incisos II e XIV, respectivamente, a Constituição de 1988 dispõe acerca da garantia de assistência pública e saúde às pessoas com deficiência, ressaltando caráter prioritário no atendimento, bem como traz a competência concorrente, ou seja, simultânea da União, Estados e do Distrito Federal para legislar na tutela da proteção e integração desses indivíduos, objetivando combater a segregação. Percebe-se, deste modo, a abrangência de imposição da Carta Magna, a fim de que, caso haja algum ente federativo que não tenha legislado acerca dos direitos da pessoa com deficiência, o outro o faça sem restrições.

Art. 23 - É competência comum da União, dos Estados, do Distrito Federal e dos Municípios:

[...]

II - cuidar da saúde e assistência pública, da proteção e garantia das pessoas portadoras de deficiência.

Art. 24 - Compete à União, aos Estados e ao Distrito Federal legislar concorrentemente sobre:

[...]

XIV - proteção e integração social das pessoas portadoras de deficiência. ${ }^{32}$

No que tange à acessibilidade, a Constituição deixa a critério de lei específica a normatização relativa à construção de logradouros e edifícios de uso público e da fabricação de veículos de transporte coletivo para garantia de acessibilidade a pessoas com deficiência, conforme dito nos arts. $227, \$ 2^{\circ}$ e 244 da Carta Magna. Se a Constituição traz a igualdade como princípio basilar, essa medida é de grande relevância, entendendo-se o direito de acesso para todos. Cabe salientar que em 2008 a Convenção Internacional das Pessoas com Deficiência foi ratificada pelo Brasil, tendo status de emenda à Constituição, através do Decreto Legislativo 186/2008. Deste modo, a defesa dos direitos da pessoa com deficiência é constitucionalmente tratada e destrinchada na referida Convenção que será analisada posteriormente.

Art. 227 - É dever da família, da sociedade e do Estado assegurar à criança e ao adolescente, com absoluta prioridade, o direito à vida, à saúde, à alimentação, à

31 BRASIL. Constituição Federal. Diário Oficial da República Federativa do Brasil, Brasília, 5 out. 1988. Disponível em: http://www.planalto.gov.br/ccivil_03/constituicao/constituicao.htm. Acesso em: 28 jun. 2017.

32 Ibidem. 
educação, ao lazer, à profissionalização, à cultura, à dignidade, ao respeito, à liberdade e à convivência familiar e comunitária, além de colocá-los a salvo de toda forma de negligência, discriminação, exploração, violência, crueldade e opressão:

[...]

$\S 2^{\circ}$ - A lei disporá sobre normas de construção dos logradouros e dos edifícios de uso público e de fabricação de veículos de transporte coletivo, a fim de garantir acesso adequado às pessoas portadoras de deficiência.

Art. 244 - A lei disporá sobre a adaptação dos logradouros, dos edifícios de uso público e dos veículos de transporte coletivo atualmente existentes a fim de garantir acesso adequado às pessoas portadoras de deficiência, conforme disposto no art. $227, \S 2^{\circ} .^{33}$

É perceptível que, a todo o momento, a Constituição da República trata a pessoa com deficiência pelo termo "pessoa portadora de deficiência”. Porém, insta salientar que o novo termo adotado pela Convenção Internacional sobre os Direitos das Pessoas com Deficiência, promulgada pelo Decreto 6.949/2009 e aprovada pelo Decreto Legislativo 186/2008 passa a ser "pessoa com deficiência", demonstrando que a deficiência faz parte do corpo e, principalmente, humanizando a denominação. Ser "pessoa com deficiência” é, antes de tudo, ser pessoa humana. Nesse sentido, substitui-se o termo “deficiente", também outrora utilizado, por ser considerado como uma adjetivação à pessoa, trazendo-lhe um estigma através da linguagem. Neste caso, como a Carta Magna é de 1988, esta não foi retificada para utilização dessa terminologia assumida posteriormente.

Antes da promulgação da nova Constituição Federal, a qual foi cuidadosa em defender a acessibilidade da pessoa com deficiência, pode-se sinalizar a Lei $n^{\circ} 4.169$, de 4 de dezembro de 1962, como a primeira lei federal que tratou sobre o assunto, não utilizando o termo “acessibilidade”, entretanto trazendo soluções para o início do aprimoramento da acessibilidade no Brasil. Tal norma oficializa as convenções do Sistema Braille para uso na escrita e leitura dos cegos e do Código de Contrações e Abreviaturas Braille, um grande passo para a diminuição da barreira comunicacional das pessoas cegas. Em seu art. $1^{\circ}$, a lei diz o seguinte:

São oficializadas e de uso obrigatório em todo o território nacional, as convenções Braille, para uso na escrita e leitura dos cégos $^{34}$ e o Código de Contrações e Abreviaturas Braille, constantes da tabela anexa e aprovados pelo

33 BRASIL. Constituição Federal. Diário Oficial da República Federativa do Brasil, Brasília, 5 out. 1988. Disponível em: http://www.planalto.gov.br/ccivil_03/constituicao/constituicao.htm. Acesso em: 28 jun. 2017.

${ }^{34}$ Texto transcrito conforme original. 
Congresso Brasileiro Pró-Abreviatura Braille, realizado no Instituto Benjamin Constant, na cidade do Rio de Janeiro, em dezembro de 1957. ${ }^{35}$

Ao final de suas disposições, a lei supracitada ainda impõe sanção, em seu art. $3^{\circ}$, àqueles que não cumprirem a devida determinação, finalizando da seguinte forma:

Os infratores da presente lei não poderão gozar de quaisquer benefícios por parte da União, perdendo o direito aos mesmos aquêles ${ }^{36}$ que os tenham conseguido, uma vez verificada e comprovada a infração pelo Instituto Benjamin Constant. ${ }^{37}$

Ainda objetivando a facilitação das condições de acessibilidade às pessoas com deficiência, é promulgada a Lei $\mathrm{n}^{\circ} 7.405$ de 12 de novembro de 1985, também utilizando o termo "pessoa portadora de deficiência", a qual torna obrigatória a colocação do "Símbolo Internacional de Acesso" em todos os locais e serviços que permitam sua utilização por pessoas com deficiência. Neste sentido, essa lei facilita a acessibilidade deixando a sua obrigatoriedade explícita para aqueles que forem utilizar determinados locais e serviços, antes, ainda, de haver um tratamento constitucional sobre o referido assunto.

Após a Constituição da República de 1988, foi promulgada a Lei 8.160 de 8 de janeiro de 1991, desta vez dispondo sobre a caracterização de símbolo que permita a identificação de pessoas portadoras de deficiência auditiva, tornando obrigatória a colocação visível, do "Símbolo Internacional de Surdez" em todos os locais que possibilitem acesso, circulação e utilização por pessoas com deficiência auditiva, e em todos os serviços que forem postos à sua disposição ou que possibilitem o seu uso.

Insta salientar que todas estas leis que estão sendo citadas, apesar de não terem um conteúdo e disposições extensas em seu corpo de lei, demonstram o aperfeiçoamento e o desenvolvimento da acessibilidade na sociedade brasileira e a sua colocação como um direito fundamental de forma inegável, tendo em vista a preocupação legal em dispor acerca de cada detalhe facilitador do rompimento das barreiras porventura impostas aos indivíduos com deficiência.

\footnotetext{
35 BRASIL. Lei $n^{\circ}$ 4.169, de 4 de dezembro de 1962. Oficializa as convenções Braille para uso na escrita e leitura dos cegos e o Código de Contrações e Abreviaturas Braille. Diário Oficial da União, Brasília, 11 dez. 1962. Disponível em: http://www.planalto.gov.br/ccivil_03/leis/1950-1969/L4169.htm. Acesso em: 3 jul. 2017.

36 Texto transcrito conforme original.

${ }^{37}$ BRASIL. Lei $\mathrm{n}^{\circ}$ 4.169, de 4 de dezembro de 1962. Oficializa as convenções Braille para uso na escrita e leitura dos cegos e o Código de Contrações e Abreviaturas Braille. Diário Oficial da União, Brasília, 11 dez. 1962. Disponível em: http://www.planalto.gov.br/ccivil_03/leis/1950-1969/L4169.htm. Acesso em: 3 jul. 2017.
} 
Destaca-se que a primeira lei a tratar explicitamente do termo "acessibilidade" foi a Lei 10.048/2000, a qual garantiu às pessoas com deficiência atendimento prioritário nas repartições públicas e empresas concessionárias de serviço público, reservas de assentos em transportes públicos, deliberando também que as construções de logradouros, sanitários públicos e edifícios públicos tivessem normas de construção destinadas a facilitar o acesso e uso desses locais ${ }^{38}$.

Outra lei que tutela a acessibilidade da pessoa com deficiência é a 10.098/2000, a qual estabelece normas gerais e critérios básicos para a promoção da acessibilidade das pessoas com deficiência ou com mobilidade reduzida. Primeiramente, a referida lei estabelece o que é acessibilidade, classifica o conceito de barreiras, envolvendo as questões de ordem: arquitetônicas, urbanísticas, nos transportes e na informação e comunicação, conceituando outros termos relacionados a essa temática, a exemplo de elemento de urbanização, mobiliário urbano e tecnologia assistiva e desenho universal, de modo a não haver dualidade na interpretação legal.

A referida Lei 10.098/2000, em seus capítulos sequenciais, traz a acessibilidade nos edifícios públicos ou de uso coletivo, nos edifícios de uso privado, nos veículos de transporte coletivo e nos sistemas de comunicação e sinalização, demonstrando, assim, a importância da acessibilidade da pessoa com deficiência e demonstrando-a como um direito fundamental, principalmente relacionado ao direito de ir e vir.

Apesar das Leis 10.048 e 10.098 de 2000 terem sido de grande importância, foi preciso um Decreto que as regulamentasse e estabelecesse prazos para as adaptações nelas previstas. Assim, em 2004, foi promulgado o Decreto $n^{\circ} 5.296$ para regulamentar as leis citadas, bem como para estabelecer critérios de implementação da acessibilidade em todas as formas trazidas nas leis anteriores e, como grande avanço, foi estabelecido o Programa Nacional de Acessibilidade, integrado aos planos plurianuais, sob coordenação da Secretaria Especial dos Direitos Humanos, trazendo com ele ações previstas em seu art. 68:

Art. 68 - A Secretaria Especial dos Direitos Humanos, na condição de coordenadora do Programa Nacional de Acessibilidade, desenvolverá, dentre outras, as seguintes ações:

I - apoio e promoção de capacitação e especialização de recursos humanos em acessibilidade e ajudas técnicas;

II - acompanhamento e aperfeiçoamento da legislação sobre acessibilidade;

\footnotetext{
${ }^{38}$ BRASIL. Lei $n^{\circ} 10.098$, de 19 de dezembro de 2000. Estabelece normas gerais e critérios básicos para a promoção da acessibilidade das pessoas portadoras de deficiência ou com mobilidade reduzida, e dá outras providências. Diário Oficial da União, Brasília, 20 dez. 2000. Disponível em: http://www.planalto.gov.br/ccivil_03/leis/L10098.htm. Acesso em: 28 jun. 2017.
} 
III - edição, publicação e distribuição de títulos referentes à temática da acessibilidade;

IV - cooperação com Estados, Distrito Federal e Municípios para a elaboração de estudos e diagnósticos sobre a situação da acessibilidade arquitetônica, urbanística, de transporte, comunicação e informação;

V-apoio e realização de campanhas informativas e educativas sobre acessibilidade;

$\mathrm{VI}$ - promoção de concursos nacionais sobre a temática da acessibilidade; e

VII - estudos e proposição da criação e normatização do Selo Nacional de Acessibilidade..$^{39}$

Antes do decreto regulamentador acima descrito, tem-se como também relevante para dirimir barreiras comunicacionais a Lei $n^{0}$ 10.436, de 24 de abril de 2002, dispondo sobre a Língua Brasileira de Sinais - Libras. Além de conceituar a Libras, a lei em epígrafe ordena ao poder público que garanta formas institucionalizadas de apoiar o uso e difusão da Língua Brasileira de Sinais como meio de comunicação objetiva e de utilização corrente das comunidades surdas do Brasil. Assim, a referida lei mais uma vez estabeleceu o cumprimento de um aspecto da acessibilidade, isto é, a acessibilidade comunicacional, inserindo a Língua Brasileira de Sinais na sociedade brasileira para facilitar a comunicação das pessoas surdas.

Outra norma federal de extrema importância para o sistema legislativo brasileiro que tutela os direitos de acessibilidade da pessoa com deficiência é a Lei $n^{\circ} 11.126$ de 27 de junho de 2005, que trata do direito da pessoa com deficiência visual de ingressar e permanecer em ambientes de uso coletivo acompanhado de cão-guia. Para a garantia desta lei, o seu artigo $3^{\circ}$ traz como forma de discriminação qualquer tentativa que impeça o indivíduo com deficiência visual de usufruir do seu direito, apenando o infrator com pena de interdição e multa.

Assim foi obedecido, em tese, o comando da Constituição Federal estabelecendo que leis específicas tratassem da acessibilidade da pessoa com deficiência, principalmente no que tange à construção de logradouros e edifícios de uso público e da fabricação de veículos de transporte coletivo, bem como no que diz respeito a facilitar a comunicação das pessoas com deficiência, principalmente auditiva e visual.

Por fim, por ser signatário da Convenção Internacional dos Direitos da Pessoa com Deficiência, o Brasil, através do Decreto 6.949 de 25 de agosto de 2009, que tem força de emenda constitucional por se tratar de tratado internacional acerca de direitos humanos e ter

39 BRASIL. Decreto 5.296, de 02 de dezembro de 2004. Regulamenta as Leis nos 10.048 , de 8 de novembro de 2000 , que dá prioridade de atendimento às pessoas que especifica, e 10.098 , de 19 de dezembro de 2000, que estabelece normas gerais e critérios básicos para a promoção da acessibilidade das pessoas portadoras de deficiência ou com mobilidade reduzida, e dá outras providências. Diário Oficial da União, Brasília, 3 dez. 2004. Disponível em: http://www.planalto.gov.br/ccivil_03/_ato20042006/2004/decreto/d5296.htm. Acesso em: 3 jul. 2017. 
sido aprovado, em cada Casa do Congresso Nacional, em dois turnos, por três quintos dos votos dos respectivos membros, trouxe a defesa da acessibilidade, no artigo 9, dispondo o que ora segue:

A fim de possibilitar às pessoas com deficiência viver de forma independente e participar plenamente de todos os aspectos da vida, os Estados Partes tomarão as medidas apropriadas para assegurar às pessoas com deficiência o acesso, em igualdade de oportunidades com as demais pessoas, ao meio físico, ao transporte, à informação e comunicação, inclusive aos sistemas e tecnologias da informação e comunicação, bem como a outros serviços e instalações abertos ao público ou de uso público, tanto na zona urbana como na rural $(\ldots)^{40}$.

Ressalte-se que tais questões acerca da acessibilidade são também ratificadas através da Lei $n^{\circ} 13.146$ de 6 de julho de 2015 que institui a Lei brasileira de inclusão da pessoa com deficiência, conhecida também como Estatuto da Pessoa com Deficiência. Tal lei inclui, dentre outros conceitos relativos à acessibilidade, o de moradia para a vida independente da pessoa com deficiência.

Desta forma, pode-se extrair, ao máximo, o que a legislação federal infraconstitucional tutela a respeito da acessibilidade da pessoa com deficiência. O quanto exposto nessa abordagem será importante para a relação da acessibilidade com o direito humano fundamental - que será realizada a seguir -, demonstrando o que o sistema normativo brasileiro traz para a garantia da acessibilidade da pessoa com deficiência em todos os seus aspectos.

\subsection{A acessibilidade como um direito fundamental da pessoa com deficiência}

Embora a acessibilidade da pessoa com deficiência não seja explicitamente citada no artigo $5^{\circ}$ da Constituição Federal, o qual pertence ao título “Dos Direitos e Garantias Fundamentais", em uma análise mais acurada do que sejam tais direitos e entendendo o conceito e a importância da acessibilidade para a concretização do amparo da Constituição a todos os cidadãos, é possível a conclusão de que a acessibilidade da pessoa com deficiência seja compreendida como um Direito Fundamental.

Como tratado anteriormente, entende-se os Direitos Fundamentais, segundo Moraes, como sendo direitos de proteção da sociedade limitando a atuação do Estado frente à

40 BRASIL. Decreto $N^{\circ}$ 6.949, de 25 de agosto de 2009. Promulga a Convenção Internacional sobre os Direitos das Pessoas com Deficiência e seu Protocolo Facultativo, assinados em Nova York, em 30 de março de 2007. Diário Oficial da União, Brasília, DF, 26 ago. 2009. Disponível em: http://www.planalto.gov.br/ccivil_03/_ato2007-2010/2009/decreto/d6949.htm. Acesso em: 3 jul. 2017. 
população. ${ }^{41}$ No rol de direitos trazidos no artigo $5^{\circ}$ da Constituição Federal, pode-se citar alguns que se relacionam intimamente com a acessibilidade, como, por exemplo: direito à vida, à igualdade, à liberdade de expressão e à liberdade de locomoção.

Tem-se tal relação íntima supracitada porque a acessibilidade foi entendida como sendo uma forma de superação de barreiras impostas às pessoas com deficiência, sendo que cada tipo de barreira a ser "vencida" leva à associação de um direito diferente. Nesse sentido, a Lei $13.146 / 2015$ destrincha, em seu artigo $3^{\circ}$, quais seriam essas barreiras e, também, os seus tipos.

Art. 3o Para fins de aplicação desta Lei, consideram-se:

[...]

IV - barreiras: qualquer entrave, obstáculo, atitude ou comportamento que limite ou impeça a participação social da pessoa, bem como o gozo, a fruição e o exercício de seus direitos à acessibilidade, à liberdade de movimento e de expressão, à comunicação, ao acesso à informação, à compreensão, à circulação com segurança, entre outros, classificadas em:

a) barreiras urbanísticas: as existentes nas vias e nos espaços públicos e privados abertos ao público ou de uso coletivo;

b) barreiras arquitetônicas: as existentes nos edifícios públicos e privados;

c) barreiras nos transportes: as existentes nos sistemas e meios de transportes;

d) barreiras nas comunicações e na informação: qualquer entrave, obstáculo, atitude ou comportamento que dificulte ou impossibilite a expressão ou o recebimento de mensagens e de informações por intermédio de sistemas de comunicação e de tecnologia da informação;

e) barreiras atitudinais: atitudes ou comportamentos que impeçam ou prejudiquem a participação social da pessoa com deficiência em igualdade de condições e oportunidades com as demais pessoas;

f) barreiras tecnológicas: as que dificultam ou impedem o acesso da pessoa com deficiência às tecnologias. ${ }^{42}$

Observa-se que a lei em comento amplia a concepção de barreiras, portanto, aumenta as condições necessárias para que se assegure acessibilidade a pessoas com deficiência ou mobilidade reduzida.

É preciso ressaltar que a Carta Magna traz que todos são iguais perante a lei, sem distinção, garantindo o direito à vida como o direito primordial a todos, como o primário, já que se constitui como pré-requisito à existência e ao exercício dos demais direitos. 0 Estado, portanto, deve garantir, segundo Moraes, o direito à vida em dois sentidos, a garantia do nascimento com vida, dando ao nascituro condições viáveis para nascer com vida - isso está

\footnotetext{
${ }^{41}$ MORAES, Alexandre de. Direito Constitucional. São Paulo: Atlas, 2010.

42 BRASIL. Lei $n^{\circ} 13.146$, de 6 de julho de 2015. Institui a Lei Brasileira de Inclusão da Pessoa com Deficiência (Estatuto da Pessoa com Deficiência). Diário Oficial da União, Brasília, 7 jul. 2015. Disponível em: http://www.planalto.gov.br/ccivil_03/_ato2015-2018/2015/lei//13146.htm. Acesso em: 3 jul. 2017.
} 
intimamente ligado a garantia de uma saúde pública de qualidade - e, logo após, o direito de subsistência, de ter uma vida digna ${ }^{43}$.

Quando se trata do direito à vida, logo se impõe pensar na dignidade da pessoa humana, trazida no artigo $1^{\circ}$, inciso III da Carta Magna como fundamento da República Federativa do Brasil, a qual protege o ser humano, tornando-se basilar, acima de qualquer princípio. Segundo Sarlet:

[...] temos por dignidade da pessoa humana a qualidade intrínseca e distintiva de cada ser humano que o faz merecedor do mesmo respeito e consideração por parte do Estado e da comunidade, implicando, neste sentido, um complexo de direitos e deveres fundamentais que asseguram a pessoa tanto contra todo e qualquer ato de cunho degradante e desumano, como venham a the garantir as condições existenciais mínimas para uma vida saudável, além de propiciar e promover sua participação ativa e co-responsável nos destinos da própria existência e da vida em comunhão com os demais seres humanos. ${ }^{44}$ (Grifos nossos).

Pode-se, diante do exposto, associar a garantia da acessibilidade à dignidade da pessoa humana dos indivíduos com deficiência, tendo em vista que, através dela, haverá a equidade e diminuição de barreiras entre as pessoas na sociedade, o que garante uma condição mínima de vida e boa convivência. Assim, considera-se que uma sociedade não acessível é aquela que não assegura o direito à vida plena de uma pessoa com deficiência, posto que sua dignidade como cidadão não é garantida. Tem-se, então, a acessibilidade como forma de complemento do direito à vida.

A Convenção Internacional sobre os Direitos das Pessoas com Deficiência, promulgada pela ONU em 2006, também promulgada pelo Brasil através do Decreto 6.949/2009, consolidou uma nova visão e paradigma das deficiências como uma questão de direito fundamental. Essa Convenção em seu artigo 10, sobre o direito à vida, diz o seguinte:

Os Estados Partes reafirmam que todo ser humano tem o inerente direito à vida e deverão tomar todas as medidas necessárias para assegurar o efetivo desfrute desse direito pelas pessoas com deficiência, em igualdade de oportunidades com as demais pessoas ${ }^{45}$.

${ }^{43}$ MORAES, Alexandre de. Direito Constitucional. São Paulo: Atlas, 2010.

44 SARLET, Ingo Wolfgang. Dignidade da Pessoa Humana e Direitos Fundamentais na Constituição Federal de 1988. 10. ed. Porto Alegre: Livraria do Advogado, 2015.

45 BRASIL. Decreto $N^{\circ}$ 6.949, de 25 de agosto de 2009. Promulga a Convenção Internacional sobre os Direitos das Pessoas com Deficiência e seu Protocolo Facultativo, assinados em Nova York, em 30 de março de 2007. Diário Oficial da União, Brasília, DF, 26 ago. 2009. Disponível em: http://www.planalto.gov.br/ccivil_03/_ato2007-2010/2009/decreto/d6949.htm. Acesso em: 3 jul. 2017. 
Com isso, pode-se visualizar no ordenamento jurídico federal infraconstitucional a tutela da real garantia do direito à vida digna das pessoas com deficiência em igualdade de oportunidade com as demais pessoas.

Outro Direito Fundamental intrinsecamente ligado à acessibilidade é o direito à igualdade. 0 caput do artigo $5^{\circ}$ consagra serem todos iguais perante a lei, sem quaisquer distinções. Nesses termos, esse sentido de igualdade impõe-se em tratar igualmente os iguais e desigualmente os desiguais, na medida de suas desigualdades, alicerce veiculado por Aristóteles, o qual tratou a igualdade com uma perspectiva de justiça.

Em 10 de dezembro de 1948, a Declaração Universal dos Direitos Humanos expressa que a igualdade sempre foi preceito fundamental considerado internacionalmente. Assim, o pleito pela erradicação da marginalização do ser humano sempre foi elemento precípuo na luta pelos direitos humanos. Na referida declaração, pode-se perceber essa primazia pela isonomia, principalmente, em seus arts. $2^{\circ}, 6^{\circ}$ e $7^{\circ}$ :

Artigo II - Todo ser humano tem capacidade para gozar os direitos e as liberdades estabelecidos nesta Declaração, sem distinção de qualquer espécie, seja de raça, cor, sexo, idioma, religião, opinião política ou de outra natureza, origem nacional ou social, riqueza, nascimento, ou qualquer outra condição.

Artigo $\mathrm{VI}$ - Todo ser humano tem o direito de ser, em todos os lugares, reconhecido como pessoa perante a lei.

Artigo VII - Todos são iguais perante a lei e têm direito, sem qualquer distinção, a igual proteção da lei. Todos têm direito a igual proteção contra qualquer discriminação que viole a presente Declaração e contra qualquer incitamento a tal discriminação. ${ }^{46}$

Com o alicerçar deste princípio, surgiram as chamadas políticas de ações afirmativas, ou seja, "políticas de igualdade que visam garantir direitos a grupos sociais historicamente excluídos de sua cidadania plena" 47 , como busca de criar medidas especiais para garantia da igualdade entre todos os cidadãos, principalmente dos grupos discriminados. Nos Estados Unidos, antes do surgimento das ações afirmativas, surgiu uma teoria conhecida como Separate but equal (separados, mas iguais). Tal teoria consistia na separação entre brancos e negros, entretanto a eles era garantida a prestação de serviços de forma idêntica, ou seja, existiam

46 ORGANIZAÇÃO DAS NAÇÕES UNIDAS PARA A EDUCAÇÃO, A CIÊNCIA E A CULTURA. Declaração Universal dos Direitos Humanos. Adotada e proclamada pela resolução 217 A (III) da Assembléia Geral das Nações Unidas em 10 de dezembro de 1948. Brasília, 1998. Disponível em: http://unesdoc.unesco.org/images/0013/001394/139423por.pdf. Acesso em: 3 jul. 2017.

47 PIMENTEL, Susana Couto (org.) et al. Estudantes com deficiência no ensino superior: construindo caminhos para desconstrução de barreiras na UFRB. Cruz das Almas: NUPI/UFRB, 2013. 
escolas para brancos e escolas para negros, mas a qualidade do ensino deveria ser a mesma. Esta teoria foi superada pela teoria do Treatment as an equal (tratamento igualitário ou de igual para igual), a qual precisou, em muitos casos, de ações afirmativas para superar a discriminação criada.

No Brasil, segundo Pinho, com a defesa ilimitada da igualdade na Constituição Federal, pode-se concluir que esse direito é basilar para o Estado ${ }^{48}$. Insta salientar que no art. $3^{\circ}$ da Carta Magna é estabelecido, dentre as metas do país, a erradicação da pobreza e marginalização, a redução das desigualdades sociais e regionais e a promoção do "bem de todos, sem preconceitos de origem, raça, sexo, cor, idade e quaisquer outras formas de discriminação"49.

o direito fundamental à igualdade, como um princípio, é a fundamentação constitucional que a sociedade tem para exigir do Estado políticas públicas para garantia da igualdade das pessoas com deficiência. Segundo Santos e Oliveira,

A Convenção da Guatemala, ratificada no Brasil pelo Decreto $n^{\circ} 3.956 / 2001$, confirma o princípio da igualdade, afirmando que as pessoas com deficiência têm os mesmos direitos humanos e liberdades fundamentais que as demais pessoas, definindo como discriminação, com base na deficiência, toda diferenciação ou exclusão que possa impedir ou anular o exercício dos direitos humanos e de suas liberdades fundamentais. ${ }^{50}$

É válido entender que, no Brasil, diversas organizações que objetivam a busca dos direitos da pessoa com deficiência têm trabalhado para que o princípio da igualdade seja respeitado. A pessoa com deficiência, atualmente, tem adquirido direitos nas mais diversas áreas, desde o direito a acompanhante em hospitais à reserva de assentos para o lazer $^{51}$.

Um dos mais significativos alcances relacionando o direito à igualdade e a acessibilidade do indivíduo com deficiência, elencados por Santos e Oliveira, foi a Lei Federal 8.213, de 24 de julho de 1991, e o Decreto Federal 3.298, de 20 de dezembro de 1999, abrindo a oportunidade para assegurar o acesso das pessoas com deficiência ao mercado de trabalho,

\footnotetext{
48 PINHO, Rodrigo César Rebello. Teoria Geral da Constituição e Direitos Fundamentais. São Paulo: Saraiva, 2002.

${ }^{49}$ BRASIL. Constituição Federal. Diário Oficial da República Federativa do Brasil, Brasília, 5 out. 1988. Disponível em: http://www.planalto.gov.br/ccivil_03/constituicao/constituicao.htm. Acesso em: 28 jun. 2017.

50 SANTOS, Yvonete Bazbuz da Silva; OLIVEIRA, Elenilce Gomes de. 0 princípio da igualdade e a pessoa com deficiência. Revista de Ciências Humanas. Viçosa, v. 11, n, 2, p. 429-440, jul./dez. 2011. p. 437438.

51 Ibidem.
} 
instituindo que em uma empresa com mais de 100 funcionários, 2 a $5 \%$ dos cargos tem que ser preenchido por pessoas com deficiência ${ }^{52}$.

As pessoas com deficiência sempre se deparam com barreiras, tanto físicas, quanto sociais, na tentativa de viverem e exercerem a sua cidadania como qualquer outro cidadão. Entretanto, sombras da estigmatização e da discriminação histórica de ver o indivíduo com deficiência como um ser "anormal" trouxeram para a realidade social uma mazela enorme, dificultando a aceitação da pessoa com deficiência como uma pessoa humana possuidora dos mesmos direitos, sem distinção. Porém, diante dos seus direitos como cidadãos, torna-se imprescindível garantir equidade de oportunidades no acesso aos bens e serviços da sociedade, incluindo atividades educacionais, esportivas, culturais e de lazer.

Dentro da análise da acessibilidade, todas as leis federais citadas no presente trabalho objetivam a garantia do direito da igualdade das pessoas com deficiência, ainda que para muitos elas sejam analisadas como sendo indivíduos que "fogem do padrão" estabelecido como “normal” pela sociedade. Deste modo, toda e qualquer lei que busque a acessibilidade destes cidadãos está garantindo que, em suas desigualdades, eles sejam tratados de uma forma desigual, com vistas a assegurar pelo Estado o dever de preservação da igualdade para todos, ordenado pela Constituição da República e garantindo a isonomia propriamente dita.

Ainda na análise acerca da acessibilidade como um direito fundamental, outro direito a ser tratado e percebido na legislação pátria, ao tutelar garantias aos indivíduos com deficiência, é a liberdade. 0 rol de direitos fundamentais da Carta Magna consagra liberdades variadas e procura garanti-las através de diversas normas. Junto com a igualdade, a liberdade é um direito essencial para a constituição da dignidade da pessoa humana, sendo que as liberdades garantidas são defendidas partindo-se do pressuposto de autorrealização da pessoa humana, responsável pela escolha dos meios à realização de suas vontades ${ }^{53}$.

A primeira liberdade importante para correlação da acessibilidade como um direito fundamental é a liberdade de expressão. Tal liberdade é um dos mais relevantes direitos fundamentais. Dentre vários artigos que a Constituição brasileira traz sobre a liberdade de expressão, cabe ressaltar o art. 220:

\footnotetext{
52 SANTOS, Yvonete Bazbuz da Silva; OLIVEIRA, Elenilce Gomes de. O princípio da igualdade e a pessoa com deficiência. Revista de Ciências Humanas. Viçosa, v. 11, n, 2, p. 429-440, jul./dez. 2011.

${ }^{53}$ MENDES, Gilmar Ferreira; BRANCO, Paulo Gustavo Gonet. Curso de Direito Constitucional. 7. ed. São Paulo: Saraiva, 2012.
} 
A manifestação do pensamento, a criação, a expressão e a informação, sob qualquer forma, processo ou veículo não sofrerão qualquer restrição, observado o disposto nesta Constituição ${ }^{54}$.

Entretanto, ao relacionar tal direito com a acessibilidade, não se parte do pressuposto de uma luta pela não censura. A compreensão vai muito mais além do que isso, tratando-se de uma liberdade para se expor de todas as formas permitidas, mesmo diante das barreiras impostas pela sociedade que aborda os indivíduos com deficiência como limitados. Se a todos é assegurada a manifestação de pensamento, como seria tal garantia às pessoas com deficiência auditiva, bem como aos indivíduos com deficiência visual? De que forma o direito à liberdade de se expressar seria garantido a esses indivíduos?

Desta maneira, como garantia do direito fundamental da acessibilidade através da liberdade de expressão, é válido trazer duas leis federais já mencionadas que trazem a resposta para tais questionamentos feitos. A Lei 4.169/1962, que oficializa as convenções Braille para uso na escrita e leitura dos cegos, e o Código de Contrações e Abreviaturas Braille, grande marco histórico para as pessoas com deficiência visual que passaram a ter sua própria maneira de se expressar, sem restrições.

Impõe-se ratificar o acréscimo da Lei 10.436/2002 que define a Língua Brasileira de Sinais como uma forma de comunicação e expressão, de natureza visual-motora, com estrutura gramatical própria, constituindo-se num sistema linguístico de transmissão de ideias e fatos, oriundos de comunidades de pessoas surdas do Brasil. Com isto, observa-se o cuidado na aplicabilidade da lei para cada tipo de deficiência, confirmando, portanto, a hipótese da acessibilidade como um dos ramos da raiz do direito fundamental.

Voltando à essência das liberdades, outra questão na qual é possível demonstrar a necessidade da garantia da acessibilidade é a liberdade de locomoção da pessoa com deficiência física. $\mathrm{O}$ art. $5^{\circ}$ da Constituição da República, em seu inciso $\mathrm{XV}$, garante a liberdade de locomoção, no território nacional, em tempo de paz. Já o ordenamento jurídico brasileiro foi firme em trazer, inclusive através de imposições à construção civil, normas que garantem o direito de liberdade de locomoção dos indivíduos com mobilidade reduzida ou usuários de cadeira de rodas.

De acordo com o censo de 2010 do Instituto Brasileiro de Estatísticas e Geografia, 7\% da população brasileira é constituída por pessoas com deficiência física, ou seja, mais de cerca de

\footnotetext{
54 BRASIL. Constituição Federal. Diário Oficial da República Federativa do Brasil, Brasília, 5 out. 1988. Disponível em: http://www.planalto.gov.br/ccivil_03/constituicao/constituicao.htm. Acesso em: 28 jun. 2017.
} 
13,3 milhões de pessoas, o que demonstra uma parcela significativa da população que, indiscutivelmente, tem limitado o direito à sua liberdade de ir e vir. ${ }^{55}$

O Decreto 3.298/99, que dispõe sobre a Política Nacional para a Integração da Pessoa Portadora de Deficiência e consolida as normas de proteção, traz, em seu art. $2^{\circ}$, o seguinte:

Cabe aos órgãos e às entidades do Poder Público assegurar à pessoa portadora de deficiência o pleno exercício de seus direitos básicos, inclusive dos direitos à educação, à saúde, ao trabalho, ao desporto, ao turismo, ao lazer, à previdência social, à assistência social, ao transporte, à edificação pública, à habitação, à cultura, ao amparo à infância e à maternidade, e de outros que, decorrentes da Constituição e das leis, propiciem seu bem-estar pessoal, social e econômico ${ }^{56}$.

A liberdade de locomoção, portanto, o direito de "ir e vir", é fundamental para garantir esse acesso a lugares e serviços oferecidos, e, consequentemente, à vida política, social e cultural, ou seja, aos demais direitos desses cidadãos. A partir disso, como um grande avanço das normas infraconstitucionais que tutelam a acessibilidade, temos a Lei 10.098/2000, estabelecendo normas gerais e critérios básicos para a promoção da acessibilidade das pessoas com deficiência ou com mobilidade reduzida. Assim como preconiza o art. $1^{\circ}$, tal Lei impõe normas gerais e critérios básicos para a promoção da acessibilidade das pessoas portadoras de deficiência ou com mobilidade reduzida, através da supressão de barreiras e de obstáculos nas vias e espaços públicos, no mobiliário urbano, na construção e reforma de edifícios e nos meios de transporte e de comunicação.

As leis citadas e as associações feitas demonstram, indubitavelmente, como a acessibilidade da pessoa com deficiência, no ordenamento jurídico federal, bem como na Constituição da República, é trazida como direito fundamental de uma forma implícita, posto que não a explicita, citando-a abertamente, em seu artigo $5^{\circ}$.

Entretanto, através da necessária garantia da acessibilidade a todos os cidadãos, sem diferenças entre os mesmos, reafirma-se o entendimento de uma forma ímpar de que a mesma é parte das condições da autonomia e segurança da pessoa com deficiência, portanto, da sua dignidade na sociedade, garantindo-lhe a vida, a igualdade e a liberdade, sem exceção e sem distinção.

${ }^{55}$ CARTILHA DO CENSO 2010 - Pessoas com Deficiência. Secretaria de Direitos Humanos da Presidência da República (SDH/PR); Secretaria Nacional de Promoção dos Direitos da Pessoa com Deficiência (SNPD); Brasília: SDH-PR/SNPD, 2012.

${ }^{56}$ BRASIL. Decreto n ${ }^{\circ} 3.298$, de 20 de dezembro de 1999. Regulamenta a Lei no 7.853, de 24 de outubro de 1989, dispõe sobre a Política Nacional para a Integração da Pessoa Portadora de Deficiência, consolida as normas de proteção, e dá outras providências. Diário Oficial da União, Brasília, 21 dez. 1999. Disponível em: http://www.planalto.gov.br/ccivil_03/decreto/d3298.htm. Acesso em: 3 jul. 2017. 


\section{CONCLUSÃO}

Com base nos estudos apresentados e nas análises feitas, é possível concluir que a acessibilidade é garantida à pessoa com deficiência pela legislação infraconstitucional federal, mesmo que não esteja elencada, explicitamente, no rol dos direitos fundamentais, trazidos no título II da Constituição Federal.

Primeiramente, ao ser analisada na Constituição Federal, encontraram-se dispositivos que asseveravam a acessibilidade como um direito fundamental, sendo possível elencar dois artigos na Carta Magna que trazem a imposição de que leis posteriores deveriam tratar acerca da acessibilidade na construção dos logradouros e dos edifícios de uso público e de fabricação de veículos de transporte coletivo, de forma a se garantir o acesso adequado às pessoas com deficiência, sem que a organização de tais locais e equipamentos fosse um fator de segregação. Apesar de tais artigos tratarem de uma das formas de acessibilidade, ou seja, relacionada à liberdade de locomoção no território nacional, reconhece-se como avanço a abordagem dessa questão.

No decorrer deste trabalho foi possível observar e elencar, frente a problemática estabelecida, que na análise das leis federais diversas leis demonstram a acessibilidade como garantia de direitos fundamentais, envolvendo desde o direito à liberdade de expressão, ao direito à igualdade e à liberdade de locomoção, assegurando a não exclusão dos indivíduos com deficiência, mas a sua inserção na sociedade como cidadãos plenos de direitos.

Foi possível observar, ao longo do texto, que mesmo algumas leis anteriores a Constituição da República já abordavam a acessibilidade, ainda que sem citar o termo de uma forma literal. Isso é notório nas leis que asseguram à liberdade de expressão das pessoas com deficiência visual (Lei $n^{\circ} 4.169$, de 4 de dezembro de 1962) e auditiva ( $n^{\circ} 10.436$ de 24 de abril de 2002), e o direito à igualdade e à liberdade de locomoção através da colocação do "Símbolo Internacional de Acesso" (Lei n 7.405 de 12 novembro de 1985) e do "Símbolo Internacional de Surdez" (Lei 8.160 de 8 de janeiro de 1991) em todos os locais de circulação e utilização por pessoas com deficiência, facilitando tanto a sua comunicação quanto à liberdade de escolha em relação ao direito de ir e vir a lugares comuns de convivência. Tal fato se repete em 2005, através da Lei $n^{\circ} 11.126$, que trata do direito da pessoa com deficiência visual de ingressar e permanecer em ambientes de uso coletivo acompanhada de cão-guia, garantindo-lhe o direito à 
igualdade, à acessibilidade, permitida a diminuição de barreiras e a possibilidade de transitar em ambientes coletivos sem que sofra restrições ou discriminações.

Portanto, é possível perceber que, nesses diversos momentos, a intenção do legislador era incluir os indivíduos com deficiência, possibilitando-os uma condição de igualdade a todos os demais cidadãos e as condições de acesso a políticas públicas que thes garantam a inclusão em uma sociedade acessível.

Após a promulgação da Constituição da República, as Leis 10.048 e 10.098, ambas do ano de 2000, tratam da acessibilidade, utilizando tal termo pela primeira vez em lei infraconstitucional. Esse termo reaparece também, mais recentemente, na chamada Lei Brasileira de Inclusão, a Lei 13.146 de 2015. Nesses casos, observou-se uma evolução conceitual, pois a acessibilidade, que inicialmente estava restrita a questões de ordem arquitetônica e a pessoas com deficiência, foi-se ampliando para outros aspectos e passou a abranger pessoas com mobilidade reduzida.

Conclui-se, portanto, a garantia da acessibilidade como um direito fundamental, diante do fato de que as leis supracitadas objetivaram asseverar a dignidade da pessoa com deficiência, com base no princípio da isonomia, o qual defende o tratamento dos desiguais de forma desigual, na medida de sua desigualdade, apenas para fins de thes assegurar direitos. Destarte, ratifica-se que, mesmo não sendo um dos direitos fundamentais elencados, explicitamente, no rol trazido pelo título II da Constituição da República Federativa do Brasil, a acessibilidade, por toda sua importância e influência na garantia da dignidade dos indivíduos com deficiência, é assegurada e associada como um direito fundamental, no instante em que todas as leis federais supracitadas existem para que as pessoas com deficiência sejam respeitadas como seres humanos e cidadãos sem distinção, numa busca, incansável, pela inclusão e respeito.

\section{REFERÊNCIAS}

BONAVIDES, Paulo. Curso de direito constitucional positivo. São Paulo: Malheiros, 2002.

BONAVIDES, Paulo. Curso de Direito Constitucional. São Paulo: Malheiros, 2011.

BRASIL. Constituição Federal. Diário Oficial da República Federativa do Brasil, Brasília, 5 out. 1988. Disponível em: http://www.planalto.gov.br/ccivil_03/constituicao/constituicao.htm. Acesso em: 28 jun. 2017.

BRASIL. Decreto $n^{\circ} 3.298$, de 20 de dezembro de 1999. Regulamenta a Lei no 7.853, de 24 de outubro de 1989, dispõe sobre a Política Nacional para a Integração da Pessoa Portadora de 
Deficiência, consolida as normas de proteção, e dá outras providências. Diário Oficial da União, Brasília, 21 dez. 1999. Disponível em:

http://www.planalto.gov.br/ccivil_03/decreto/d3298.htm. Acesso em: 3 jul. 2017.

BRASIL. Decreto 5.296, de 02 de dezembro de 2004. Regulamenta as Leis $n^{\circ} \mathbf{0} 10.048$, de 8 de novembro de 2000, que dá prioridade de atendimento às pessoas que especifica, e 10.098, de 19 de dezembro de 2000, que estabelece normas gerais e critérios básicos para a promoção da acessibilidade das pessoas portadoras de deficiência ou com mobilidade reduzida, e dá outras providências. Diário Oficial da União, Brasília, 3 dez. 2004. Disponível em:

http://www.planalto.gov.br/ccivil_03/_ato2004-2006/2004/decreto/d5296.htm. Acesso em: 3 jul. 2017.

BRASIL. Decreto $N^{\circ} 6.949$, de 25 de agosto de 2009. Promulga a Convenção Internacional sobre os Direitos das Pessoas com Deficiência e seu Protocolo Facultativo, assinados em Nova York, em 30 de março de 2007. Diário Oficial da União, Brasília, DF, 26 ago. 2009. Disponível em: http://www.planalto.gov.br/ccivil_03/_ato2007-2010/2009/decreto/d6949.htm. Acesso em: 3 jul. 2017.

BRASIL. Lei ${ }^{\circ}$ 4.169, de 4 de dezembro de 1962. Oficializa as convenções Braille para uso na escrita e leitura dos cegos e o Código de Contrações e Abreviaturas Braille. Diário Oficial da União, Brasília, 11 dez. 1962. Disponível em: http://www.planalto.gov.br/ccivil_03/leis/19501969/L4169.htm. Acesso em: 3 jul. 2017.

BRASIL. Lei $n^{\circ} 10.098$, de 19 de dezembro de 2000. Estabelece normas gerais e critérios básicos para a promoção da acessibilidade das pessoas portadoras de deficiência ou com mobilidade reduzida, e dá outras providências. Diário Oficial da União, Brasília, 20 dez. 2000. Disponível em: http://www.planalto.gov.br/ccivil_03/leis/L10098.htm. Acesso em: 28 jun. 2017.

BRASIL. Lei $n^{\circ}$ 13.146, de 6 de julho de 2015. Institui a Lei Brasileira de Inclusão da Pessoa com Deficiência (Estatuto da Pessoa com Deficiência). Diário Oficial da União, Brasília, 7 jul. 2015. Disponível em: http://www.planalto.gov.br/ccivil_03/_ato2015-2018/2015/lei/l13146.htm. Acesso em: 3 jul. 2017.

CARTILHA DO CENSO 2010 - Pessoas com Deficiência. Secretaria de Direitos Humanos da Presidência da República (SDH/PR); Secretaria Nacional de Promoção dos Direitos da Pessoa com Deficiência (SNPD); Brasília: SDH-PR/SNPD, 2012.

FERRAJOLI, Luigi. Derechos y garantías. La ley del más débil. Madrid: Trotta, 1999.

JANCZESKI, Célio Armando (Coord.). Constituição Comentada. Curitiba: Juruá, 2011.

MENDES, Gilmar Ferreira; BRANCO, Paulo Gustavo Gonet. Curso de Direito Constitucional. 7. ed. São Paulo: Saraiva, 2012.

MENDES, Gilmar Ferreira; COELHO, Inocêncio Mártires; BRANCO, Paulo Gustavo Gonet. Curso de direito constitucional. 3. ed. São Paulo: Saraiva, 2008.

MORAES, Alexandre de. Direito Constitucional. São Paulo: Atlas, 2010. 
ORGANIZAÇÃO DAS NAÇÕES UNIDAS PARA A EDUCAÇÃO, A CIÊNCIA E A CULTURA. Declaraçãa Universal dos Direitos Humanos. Adotada e proclamada pela resolução 217 A (III) da Assembléia Geral das Nações Unidas em 10 de dezembro de 1948. Brasília, 1998. Disponível em: http://unesdoc.unesco.org/images/0013/001394/139423por.pdf. Acesso em: 3 jul. 2017.

PFAFFENSELLER, Michelli. Teoria dos direitos fundamentais. 2007. Disponível em: http://www.planalto.gov.br/ccivil_03/revista/Rev_85/artigos/MichelliPfaffenseller_rev85.htm. Acesso em: 2 abr. 2014.

PIMENTEL, Susana Couto (org.) et al. Estudantes com deficiência no ensino superior: construindo caminhos para desconstrução de barreiras na UFRB. Cruz das Almas: NUPI/UFRB, 2013.

PINHO, Rodrigo César Rebello. Teoria Geral da Constituição e Direitos Fundamentais. São Paulo: Saraiva, 2002.

PINTO, Alexandre Guimarães Gavião. Direitos fundamentais - legítimas prerrogativas de liberdade, igualdade e dignidade. 2010. Disponível em:

http://www.tjri.jus.br/c/document_library/get_file?uuid=ae67daf5-7ca9-408c-93b6b58186a81197. Acesso em: 31 mar. 2014.

SANTOS, Yvonete Bazbuz da Silva; OLIVEIRA, Elenilce Gomes de. O princípio da igualdade e a pessoa com deficiência. Revista de Ciências Humanas. Viçosa, v. 11, n, 2, p. 429-440, jul./dez. 2011.

SARLET, Ingo Wolfgang. Dignidade da Pessoa Humana e Direitos Fundamentais na Constituição Federal de 1988. 10. ed. Porto Alegre: Livraria do Advogado, 2015.

\section{COMO FAZER A REFERÊNCIA DO ARTIGO (ABNT):}

PIMENTEL, Susana Couto; PIMENTEL, Mariana Couto. Acessibilidade como um direito fundamental: uma análise à luz das leis federais brasileiras. Revista Eletrônica do Curso de Direito da UFSM, Santa Maria, RS, v. 13, n. 1, p. 75-102, abr. 2018. ISSN 1981-3694. Disponível em: <https://periodicos.ufsm.br/revistadireito/article/view/27961>. Acesso em: dia mês. ano. doi: http://dx.doi.org/10.5902/1981369427961. 